\title{
Identification of weed-suppressive tomato cultivars for weed management
}

Isabel Schlegel Werle ${ }^{1}$, Edicarlos Castro ${ }^{2}$, Carolina Pucci ${ }^{3}$, Bhawna Soni Chakraborty ${ }^{4}$, Shaun R. Broderick ${ }^{5}$ and Te Ming Tseng 6*

\author{
University of Arkansas; iswerle@uark.edu \\ Mississippi State University; ebd88@msstate.edu \\ 3 São Paulo State University, carolpuccim@gmail.com \\ 4 Virginia Polytechnic Institute and State University, bhawnasoni23@gmail.com \\ 5 Mississippi State University; srb559@msstate.edu \\ 6 Mississippi State University; t.tseng@msstate.edu \\ * Correspondence: t.tseng@msstae.edu
}

\begin{abstract}
The present study aims to identify tomato (Solanum lycopersicum L.) cultivars with weedsuppressive ability against target weed species in the tomato growing season. A greenhouse study was conducted with 17 tomato cultivars and target weeds Palmer amaranth (Amaranthus palmeri S. Wats), yellow nutsedge (Cyperus esculentus L.), and large crabgrass (Digitaria sanguinalis L.). Tomato plants and weed species were grown in the same pot. The height, chlorophyll, and dry weight biomass of the weeds were measured 28 days after sowing. The largest effect of tomato interference was on Palmer amaranth. Cultivar 15 reduced Palmer amaranth height, chlorophyll, and biomass by 58,28 , and $83 \%$, respectively. Chlorophyll percentage of yellow nutsedge seedlings was suppressed by $15 \%$ by cultivar 64 , whereas $13 \%$ of its height was reduced by cultivar 20 . Cultivar 15 reduced biomass of yellow nutsedge by $40 \%$. The percentage of chlorophyll of large crabgrass was reduced by $22 \%$ with cultivar 5 , whereas the height and biomass were reduced by 35 and $44 \%$ with cultivars 38 and 63, respectively. Factoring all parameters evaluated, cultivars 38, 33, and 7 were most suppressive against the problematic weed species in tomato.
\end{abstract}

Keywords: tomato cultivar; allelopathy; competitive ability; plant-plant interactions; weed suppression; sustainable weed management; weed management; vegetable

\section{Introduction}

Tomato is an economically important vegetable in the United States. In 2019, there was 110,700 ha of tomato harvested, with a national average yield of $44,000 \mathrm{~kg} \mathrm{ha}^{-1}$ [1]. Weed management is one of the costliest practices in tomato production, and it is considered a significant portion of the total operating cost to farmers [2]. Notably, weed thresholds acceptable to growers of high-value vegetables such as fresh and processed tomato are near zero.

Palmer amaranth (Amaranthus palmeri S. Wats.), yellow nutsedge (Cyperus esculentus L.), and large crabgrass (Digitaria sanguinalis L.) are among the primary weed species interfering in tomato farming [3]. The season-long presence of 25 yellow nutsedge plants $\mathrm{m}^{2}$ can reduce tomato yield by $25 \%$ [4]. Furthermore, field infestations of large crabgrass at a density of 55 plants $\mathrm{m}^{2}$ in direct-seeded tomato can cause up to $74 \%$ yield 
reduction [5]. In transplanted tomato crops, a decrease of $76 \%$ was observed in productivity under infestation of Amaranthus spp. [6]. Physical and chemical interactions govern the interference of these weed species. Essentially, plant-plant interaction is comprised of two factors: allelopathy and competition [7]. Competition is the physical perception of surrounding environmental resources available. At the same time, allelopathy is a chemical-mediated interference associated with the release of compounds from a donor plant that can influence the growth and performance of a receiving plant [8]. Resource competition has driven plant community interactions, but recently allelopathy has emerged as an approach to solve issues in agricultural fields.

Scientific interest in allelopathy as a tool is driven by the threat of increasing herbicide-resistant weeds, the need for alternative weed control for high labor-input crops, and the increasing demand for organically grown-derivate products [9,10]. Allelopathic properties have been found in cereal crops, such as rye, sorghum, rice, and wheat, and leguminous as sunflower and rapeseed [11]. Some well-studied phytochemicals include simple phenolics, flavonoids, and alkaloids [12]. The allelopathic property of some plants is potentially valuable for intercropping systems, soil additives via crop residue incorporation, and suppression of weed emergence [13]. The discovery of commercial crops that can suppress weeds by releasing allelopathic compounds has been considered as a selection criterion for its use in several places in the world [10]. However, limited knowledge is available, especially for vegetable crops. Therefore, this research aimed to identify tomato cultivars with allopathic properties and competitive ability to suppress problematic weeds in tomato production.

\section{Results}

The allelopathic potential of tomato accessions was calculated based on height, shoot dry biomass, and chlorophyll reduction of three weed species. The greenhouse sudy was conducted over four weeks.. Weed height, chlorophyll, and shoot biomass were significantly affected by the interference of tomato cultivars $(\mathrm{p}<0.05)$. Chlorophyll reduction percentage was relatively low for all weed species evaluated (Table 1). The chlorophyll reduction of Palmer amaranth ranged from 12 to $24 \%$, and cultivar 15 caused the highest reduction (Table 1). Yellow nutsedge seedlings had less than $20 \%$ of chlorophyll reduction. Cultivar 64 reduced yellow nutsedge chlorophyll the most, while cultivars 31,54,18, and 40 caused only a 5\% reduction. Cultivar 15 had the most considerable effect on the chlorophyll of large crabgrass plants (22\%). However, 35\% of tomato cultivars caused less than $15 \%$ of reduction.

Regarding seedling height, Palmer amaranth was the most affected by tomato cultivars among the weed species (Figure 1). Height reduction of Palmer amaranth ranged from 18 to $45 \%$. Cultivars 41 and 15 stunted Palmer amaranth height the most ( 45 and $44 \%$, respectively) but was statistically similar to the other cultivars (Figure 2). The effect of interference treatments on yellow nutsedge height was similar and followed the same trends. Cultivar 20 provided the largest stunt of the seedlings, 77\% more than cultivars 5, 44,59 , and 54 . Overall, a range of 20 to $35 \%$ of height reduction was found in large 
crabgrass plants. Large crabgrass height was reduced $35 \%$ in cultivar 38 compared with the weed in monoculture, which did not differ from the other cultivars.

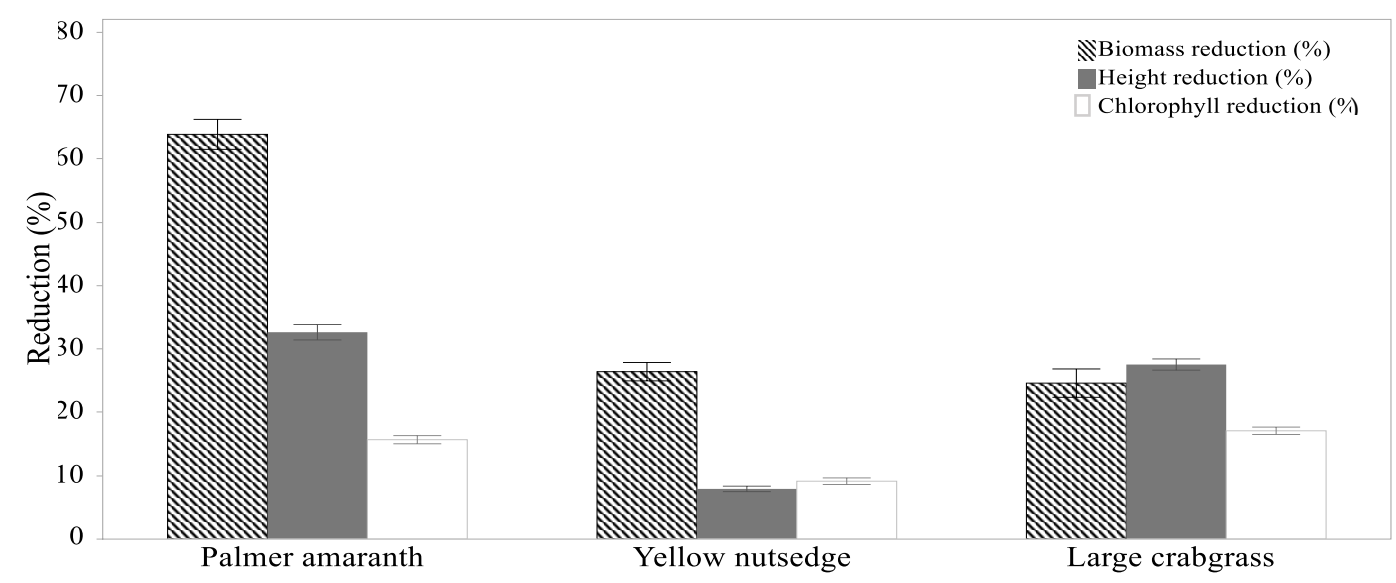

Figure 1. Average seedling height, biomass, and chlorophyll reduction (\%) of Palmer amaranth, yellow nutsedge, and large crabgrass at 28 days after sowing.

Table 1. Percentage of chlorophyll reduction of Palmer amaranth, yellow nutsedge, and large crabgrass across 17 tomato cultivars at 28 days after sowing.

\begin{tabular}{|c|c|c|c|}
\hline \multirow[b]{2}{*}{ Cultivar } & \multicolumn{3}{|c|}{ Chlorophyll Reduction (\%) } \\
\hline & Palmer amaranth & yellow nutsedge & large crabgrass \\
\hline 5 & 15 & 14 & 22 \\
\hline 7 & 18 & 8 & 19 \\
\hline 10 & 18 & 6 & 20 \\
\hline 15 & 23 & 8 & 11 \\
\hline 17 & 15 & 8 & 21 \\
\hline 18 & 15 & 5 & 9 \\
\hline 20 & 17 & 10 & 13 \\
\hline 31 & 14 & 5 & 11 \\
\hline 33 & 12 & 11 & 18 \\
\hline 38 & 15 & 9 & 19 \\
\hline 40 & 16 & 5 & 22 \\
\hline 41 & 16 & 7 & 20 \\
\hline 44 & 17 & 12 & 20 \\
\hline 54 & 14 & 4 & 15 \\
\hline 59 & 13 & 11 & 15 \\
\hline 63 & 13 & 12 & 16 \\
\hline 64 & 14 & 15 & 17 \\
\hline LSD (0.05) & 1.96 & 1.96 & 1.96 \\
\hline
\end{tabular}




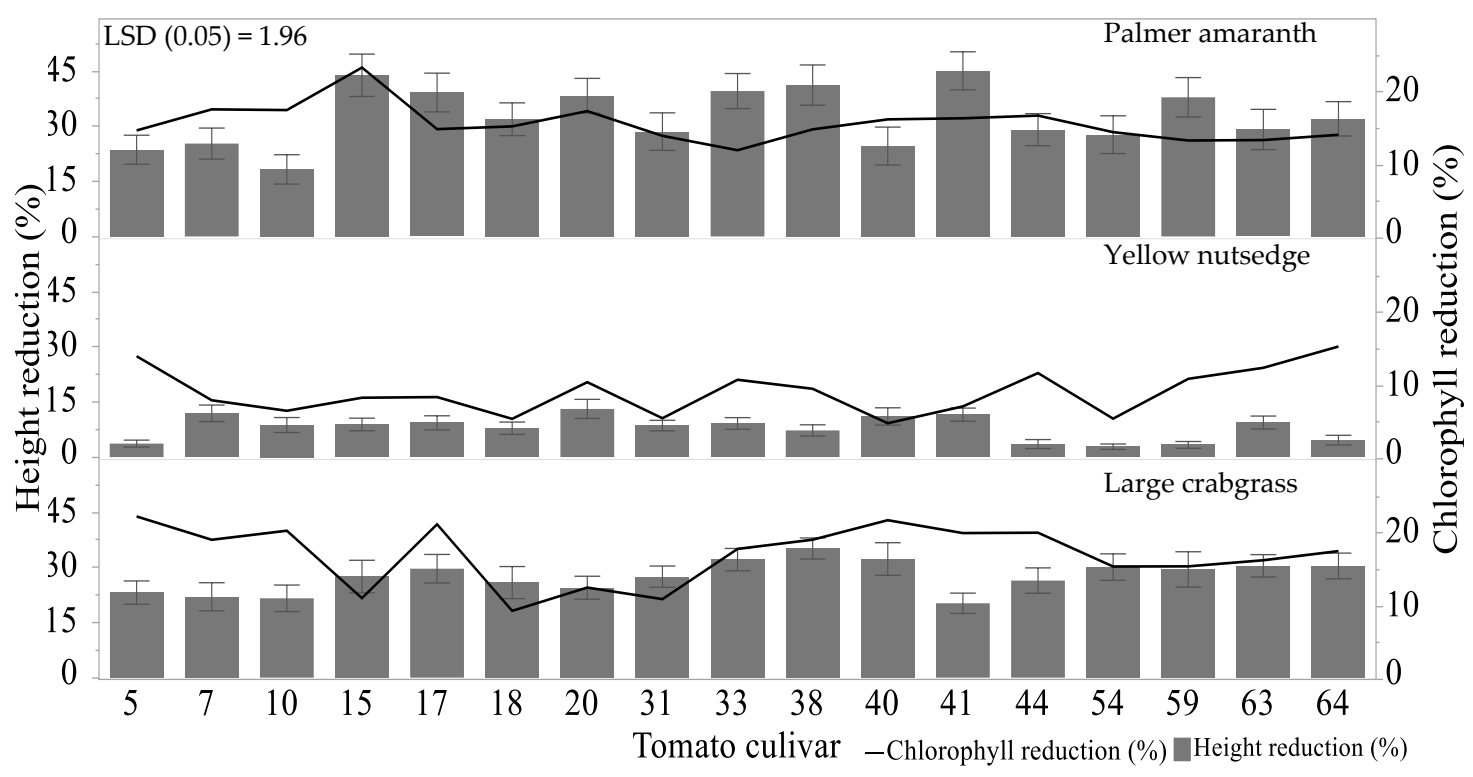

Figure 2. Weed suppressive ability of tomato cultivars on height reduction (\%) and chlorophyll reduction (\%) of Palmer amaranth, large crabgrass, and yellow nutsedge at 28 days after sowing.

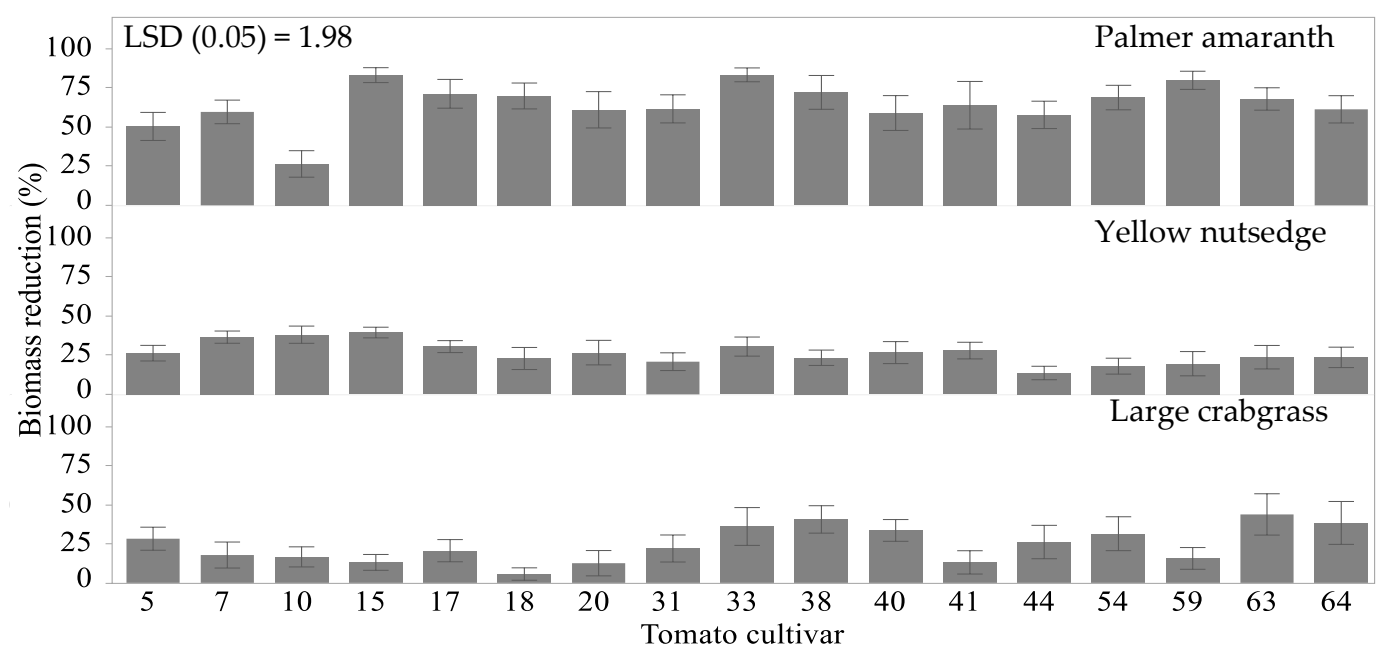

Figure 3. Weed suppressive ability of tomato cultivars on biomass reduction (\%) of Palmer amaranth, large crabgrass, and yellow nutsedge at 28 days after sowing. 

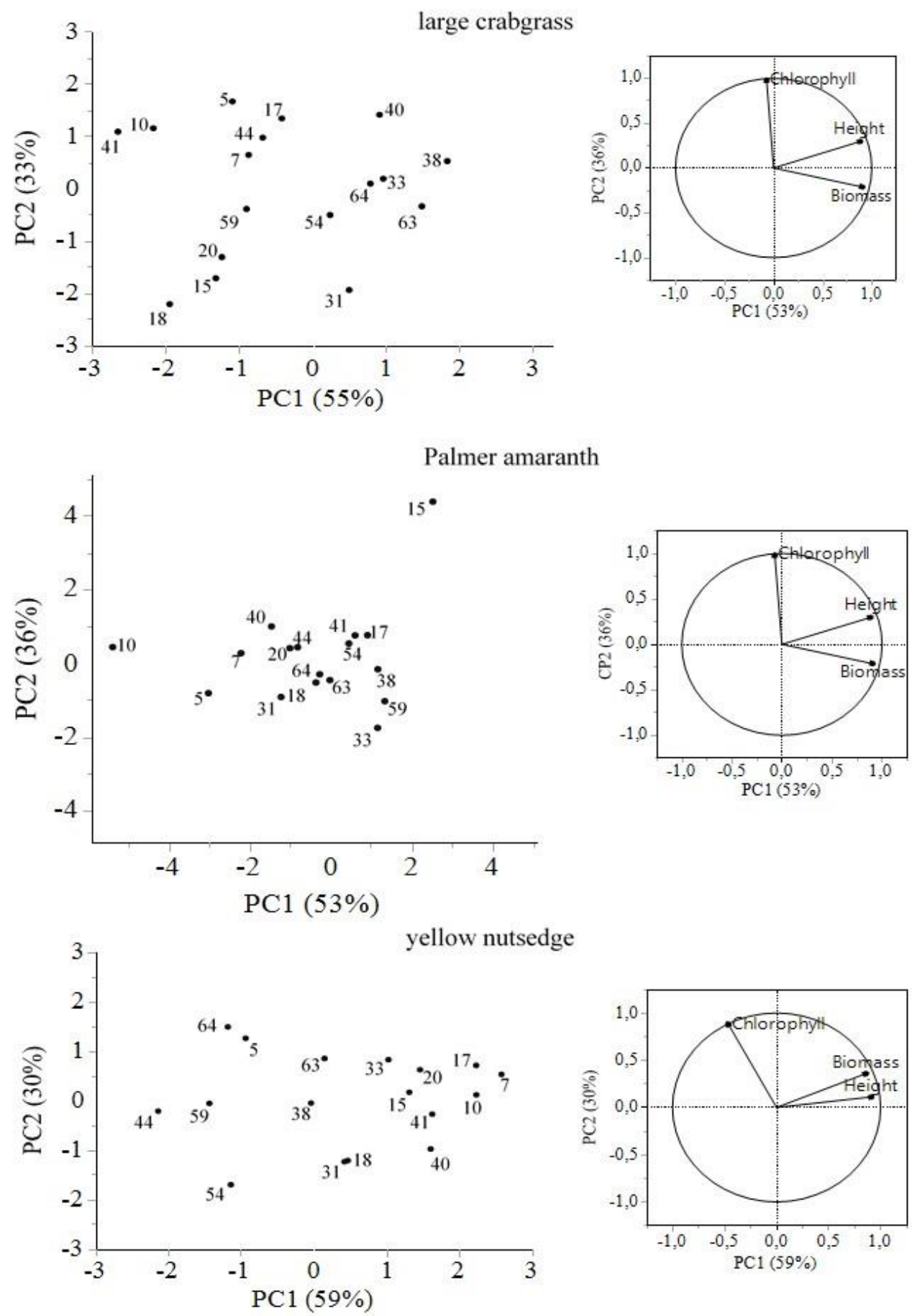

Figure 4. Principal component analysis (PCA) based on three components, height, chlorophyll, and biomass. The proportion of variances for principal components (PC) 1 and 2 are shown in parentheses.

Palmer amaranth shoot biomass was considerably decreased with the interference of tomato cultivars, and the percentage of reduction range from 26 to $83 \%$ (Figure 1). The maximum reduction of dry biomass found in Palmer amaranth was due to the influence of the tomato cultivars 33 and 15, whereas the minimum biomass reduction was observed 
with cultivar 10 (Figure 3). Yellow nutsedge biomass decreased 39\% with the interference of cultivar 15 , which was $64 \%$ greater than when large crabgrass plants interfered with tomato cultivar 44 . Overall, $60 \%$ of tomato cultivars resulted in biomass reduction of large crabgrass by more than $20 \%$. Among the cultivars, the highest biomass reduction in large crabgrass was due to cultivar 63 (44\%). The least suppressive effect was observed with cultivar 18 (5\%).

The Principal Component Analysis (PCA) was performed to accurately identify the most contributing traits in suppressing weed species. Principal component 1 contributed $55 \%$ of the total variability of large crabgrass, whereas $33.2 \%$ of the variation can be attributed to component 2 (Figure 4). In Palmer amaranth, the principal component 1 (PC1) accounted for $53.5 \%$ of the total variation in the dataset, and PC2 for $36.4 \%$. PCA of yellow nutsedge revealed that $59.4 \%$ of the variation in allelopathic potential was related to component 1 , and $30.5 \%$ was related to component 2 . Among the parameters used, height reduction and biomass reduction were found to be positively correlated with component 1 , but chlorophyll reduction was not closely related to these parameters. From the PCA analysis, tomato cultivars 38 and 63 clustered together in the PC1, indicating high allopathic potential on large crabgrass plants. Cultivars 38, 59, and 33 exhibited high suppression on Palmer amaranth. Yellow nutsedge was affected the most by cultivars 7 , 10 , and 17.

\section{Discussion}

Various chemical responses are released from plants upon stressful conditions of interference of neighboring plant species $[14,15]$. One method to verify the results from plant exudates is by growing plants that present allelopathy properties close to target weeds [16]. This trait can be herewith confirmed by its effects on the growth and biomass of the receiver plants. Alternatively, the receiver plant suppression can occur partly due to competition for space. Although it was not possible to eliminate the effects of competition in our experimental design, the allelopathic inhibitory effect of some cultivars was apparent.

The interference caused by the tomato cultivars on weed species varied widely. A hierarchical response was observed among the measured variables, where biomass and height reduction were the most affected by tomato cultivars across all weed species tested, while chlorophyll reduction had the least response due to tomato interference. Allelopathy interference can affect physiological and biochemical plant mechanisms such as photosynthesis, the metabolism process, and the synthesis of key proteins and enzymes $[17,18]$. Chlorophyll contents are essential in the basic physiological processes for plant growth and development $[19,20]$. Essential oil derivated from lemongrass (Cymbopogon citratus) is known to present allelopathic potential. The increased concentration of this essential oil decreased the chlorophyll a and $\mathrm{b}$ carotenoid content of barnyardgrass (Echinochloa crus-galli). At a concentration of 10 and 5\%, contents of chlorophyll a were reduced by 48 and $29 \%$, whereas chlorophyll b was decreased by $48 \%$ and $34 \%$, respectively [21]. However, when exposed to exudates of peppermints, the chlorophyll content of tomato seedlings was not affected [22]. The present study showed no 
differences in the chlorophyll percentage present in the weed species due to interference of tomato cultivars. Overall, chlorophyll reductions were not greater than $20 \%$ (Table 2).

Competition or competitive behaviors lead plants to defend themselves by allocating resources to energy-costly defense mechanisms [23]. Therefore, rather than investing in growth and biomass production, plants tend to present stunting due to stress conditions $[24,25]$. Our results show that the seedling height of Palmer amaranth and large crabgrass was highly affected under the interference of tomato cultivars. However, the reduction of yellow nutsedge growth was less than $10 \%$ under interference of tomato cultivars. Yellow nutsedge shoots were above tomato canopy throughout the study, indicating that competition for light between the crop and the weed could contribute to the lower height reduction observed in this species. A greenhouse study conducted with full-season interference of a single yellow nutsedge plant reduced tomato shoot dry biomass by $19 \%$ compared with weed-free tomato [4]. Since the interference of tomato cultivars reduced the growth of the weed species, their biomass accumulation was also affected. Except for cultivar 10, the shoot biomass of Palmer amaranth was decreased by more than $50 \%$ under the interference of tomato. Large crabgrass and yellow nutsedge exhibited no more than $30 \%$ of biomass reduction in the presence of the tomato cultivars.

The genetic background of the genotypes can influence the potential of tomato cultivars in suppressing weeds. In this study, the allelopathic potential of tomatoes varied within cultivars. The influence of tomato cultivars also varied among each parameter measured. The variation among the parameters measured can be a result of the multiple metabolites produced by the cultivars. The mechanism of action of these metabolites can be compared to chemical herbicides. In other words, plant exudates can have different effects depending on the compound present. Thus their target within the plant and the response of the receiver is diverse and complex [26, 27]. Tomato cultivars 38 and 33 were highly suppressive in this screening based on all the three parameters measured. However, cultivar 7 performed well in this study against yellow nutsedge. Tomato cultivars were most suppressive against Palmer amaranth at the early stages; on the other hand, little effect was observed on yellow nutsedge seedlings. The data generated in this study are encouraging, as they show that tomato cultivars are likely to have a significant impact on weed suppression. Tomato growers can benefit from this research by selecting genotypes with advantaged characteristics against weeds, especially where Palmer amaranth is a problem. These cultivars can also be used as a source of genes in tomato breeding to develop high-yielding and weed-suppressive commercial tomato cultivars. Our results are a step forward in sustainable tomato production both for conventional and organic farmers.

\section{Materials and Methods}

This study was conducted over three years (2017 to 2019) at the Mississippi State University at the R. R. Foil Plant Science Research Center $\left(88.7847^{\circ}, 33.4552^{\circ}\right)$, Starkville, MS. Weed suppressive potential of 17 tomato cultivars (Table 2) were tested on Palmer amaranth (Palmer amaranth S. Wats), yellow nutsedge (Cyperus esculentus L.) and large crabgrass (Digitaria sanguinalis L.). A weed-only pot was used as a control treatment. Tomato and weed seeds were evenly spread in 10-liter pots filled with a mixture of field 
soil and commercial potting mix (2:1). Field soil was used as the growth medium to minimize chemical inhibition by using the organic substrate. To avoid water contact with plant shoot, the pots were placed in trays filled with water according to their necessity. The species were co-located in the same potting container. Thus, both species could also generate chemical interference due to the release of allelochemicals from root exudates. Tomato seeds were sown on the edge of the pot, while the seeds of the weeds were sown at the center of the pot. At the moment of emergence, weed seedlings were thinned to four per pot.

Table 2. Code and names of 17 tomato cultivars tested for suppressive ability on Palmer amaranth, yellow nutsedge, and large crabgrass.

\begin{tabular}{cc}
\hline Cultivar code & Cultivar name \\
\hline 5 & AVTO 9802 \\
7 & 1595 \\
10 & 114 \\
15 & 1511 \\
17 & 2079 \\
18 & 2709 \\
20 & 1512 \\
31 & 1458 \\
33 & 2661 \\
38 & 168 \\
40 & 3056 \\
41 & 2401 \\
44 & 1511 \\
54 & M82 \\
59 & FERRY MORSE \\
63 & AVTO 1219 \\
64 & WV63 \\
\hline
\end{tabular}

The pots were laid out in a completely randomized design, with four replications. The experiment was repeated twice for each cultivar and weed species. The four central weed plants were considered for the evaluations. Plant height, chlorophyll, and dry weight biomass of the weeds were measured 28 days after sowing (DAS). The height of the weeds was measured from the soil to the insertion of the last leaf. Chlorophyll was evaluated using a CCM-300 spad meter (Opti-Sciences Inc., Hudson, USA). At 28 DAS, plants were cut at the soil surface and stored in paper bags. Samples were dried in a forced-air circulation oven at $60^{\circ} \mathrm{C}$ until constant weight. Comparison among weed species was based on percent inhibition data. Height, chlorophyll, and biomass reduction percentage of recipient plant and donor plant samples were calculated as:

$$
\text { reduction }(\%)=100-\underline{\text { (receiver plant } \times 100)}
$$$$
\text { (control plant) }
$$ 
Whereas the control is the mean height, chlorophyll, or biomass of all the plants in the four control pots combined, and the height, chlorophyll, or biomass receiver is based on weed plant grown together with the tomato cultivars. The highest and lowest ranking accession were determined by Principal Component Analysis (PCA) on each weed species based on height, chlorophyll, and biomass. Data were analyzed using a general linear model with mean values separated using Fisher's Protected Least Significant Difference at a 0.05 probability level using JMP 15.2.0 software (SAS Institute Inc., Cary, NC).

\begin{abstract}
Author Contributions: Conceptualization, T.M.T.; methodology, E.C., C.P., I.S.W., and T.M.T.; software, I.S.W.; validation, I.S.W., and T.M.T.; formal analysis, I.S.W.; investigation, E.C., C.P., I.S.W., and B.S.C.; resources, S.R.B. and T.M.T.; data curation, E.C., C.P., I.S.W., and B.S.C.; writing-original draft preparation, I.S.W.; writing - review I.S.W., S.R.B., and T.M.T.; visualization, I.S.W. and T.M.T.; supervision, T.M.T.; project administration, T.M.T.; funding acquisition, T.M.T. All authors have read and agreed to the published version of the manuscript.
\end{abstract}

Funding: Funding for this project was provided by the Mississippi Department of Agriculture and Commerce/United States Department of Agriculture Specialty Crop Block Grant Program. This material is based upon work that is supported by the National Institute of Food and Agriculture, US Department of Agriculture, Hatch project under accession number 230100.

Institutional Review Board Statement: Not applicable.

Informed Consent Statement: Not applicable.

Data Availability Statement: Not applicable.

Conflicts of Interest: The authors declare no conflict of interest.

\title{
References
}

1. [USDA] U.S. Department of Agriculture. State Agriculture Overview. Available online: https://downloads.usda.library.cornell.edu/usdaesmis/files/02870v86p/gm80j322z/5138jn50j/vegean19.pdf (accessed on 10 February 2021).

2. Devkota P.; Norsworthy, J.K.; Rainey, R. Comparison of allyl isothiocyanate and metham sodium with methyl bromide for weed control in polyethylene-mulched bell pepper. Weed Technol 2013, 27, 468-474; DOI:10.1614/WT-D-12-00174.1

3. Webster, T.; M. Weed survey -Southern states: Vegetable, fruit and nut crops subsection. Proc. South. Weed Science Society 2014, 55, 237-258.

4. Morales-Payan, J.P.; Stall, W.M.; Shilling, D.G.; Charudattan, R.; Dusky, J. A.; Bewick, T. A. Above and below-ground interference of purple and yellow nutsedge (Cyperus spp.) with tomato. Weed Sci 2003, 51, 181-185; DOI:10.1614/00431745(2003)051[0181:AABIOP]2.0.CO;2

5. Monaco, T.J., Grayson, A.S., Sanders, D.C. Influence of four weed species on the growth, yield, and quality of direct-seeded tomatoes (Lycopersicon esculentum). Weed Sci 1981, 29, 394-397; DOI:10,1017/S0043174500039874

6. Qasem, J. R. Pigweed (Amaranthus spp.) interference in transplanted tomato (Lycopersicon esculentum). Journal of Horticultural Science 1992, 67, 421-427. DOI: 10.1080/00221589.1992.11516267

7. Olofsdotter, M., Jensen, L.B., and Courtois, B. Improving crop competitive ability using allelopathy $Đ$ an example from rice. J Plant Breeding 2002, 121, 1-9; DOI:10.1046/j.1439-0523.2002.00662.x

8. Muller, C.H. Allelopathy as a Factor in Ecological Process. Vegetatio 1969, 18, 348-357; DOI:10.1007/BF00332847

9. Hoad, S.P.; Bertholdsson, N.; Neuhoff, D.; Köpke, U. Approaches to breed for improved weed suppression inorganically grown cereals. Organic Crop Breed 2012, 61-76; DOI: 10.1002/9781119945932.ch4

10. Worthington, M.; Reberg-Horton, C. Breeding cereal crops for enhanced weed suppression: optimizing allelopathy and competitive ability. Journal of Chemistry Ecology 2013, 39, 213-231; DOI: 10.1007/s10886-013-0247-6 
11. Olofsdotter, M.; Navarez, D.; Rebulanan, M.; Streibig, J.C. Weed suppressing rice cultivars - does allelopathy play a role? Weed Res. 1999, 39, 441-454; DOI: 10.1046/j.1365-3180.1999.00159.x

12. Macías, F.A.; Mejpias, F.J.R.; Molinillo, J.M.G. Recent advances in allelopathy for weed control: from knowledge to applications. Pest Manag Sci 2019, 75, 2413-2436; DOI: 0.1002/ps.5355

13. Farooq, M.; Bajwa, A.A.; Cheema, S.A.; Cheema, Z.A. Application of allelopathy in crop production Int. J. Agric. Biol. 2013, 15, 1367-1378; DOI: 10.1007/978-3-642-30595-5_6

14. Lankau, R. A. Coevolution between invasive and native plants driven by chemical competition and soil biota. Proc. Natl. Acad. Sci. U.S.A. 2012, 109, 11240-11245; DOI: 10.1073/pnas.1201343109

15. Pierik, R., Mommer, L., and Voesenek, L. A. Molecular mechanisms of plant competition: neighbour detection and response strategies. Funct. Ecol. 2013, 27, 841-853; DOI: 10.1111/1365-2435.12010

16. Tesio, F.; Ferrero, A. Allelopathy, a chance for sustainable weed management. International Journal of Sustainable Development \& World Ecology 2010, 17, 377-389; DOI: 10.1080/13504509.2010.507402

17. Hosseinzade, M.; Kiarostami, K.H; Ilkhanizadeh, M.; Saboora, A. A study on allelopathic compounds derived from Hordeum spontaneum on carbohydrates, proteins and some enzymes of wheat (Triticum aestivum L.). Iran.J.Biol. 2009, $22,392-406$.

18. Soares,A.R., Cássia Siqueira-Soares,Rd,Salvador,V.H.,Lourdes Lucio Ferrarese, Md, Ferrarese-Filho,O. The effect sofl-DOPA on root growth, lignification and enzyme activity in soybean seedlings. Acta Physiol. Plant 2012, 34,1811-1817; DOI:10.1007/s11738012-0979-x

19. Qian, H.; Xu, X.; Chen, W.; Jiang, H.; Jin Y., Liu, W.; Fu, Z. Allelochemical stress causes oxidative damage and inhibition of photosynthesis in Chlorella vulgaris. Chemosphere 2009, 75, 368-375; DOI: 10.1016/j.chemosphere.2008.12.040

20. Zhou, Y., YU, J. Allelochemicals and photosynthesis allelopathy. Springer, Dordrecht 2006, 127-139; DOI:10.1007/1-4020-42809_6

21. Poonpaiboonpipat, T.; Pangnakorn, U.; Suvunnamek, U.; Teerarak, M.; Charoenying, P.; Laosinwattana, C. Phytotoxic effects of essential oil from Cymbopogon citratus and its physiological mechanisms on barnyardgrass (Echinochloa crus-galli). Ind. Crop. Prod. 2013,41, 403-407; DOI: 10.1016/j.indcrop.2012.04.057

22. Mahdavikia, F.; Saharkhiz, J.M. Secondary metabolites of peppermint change the morphophysiological and biochemical characteristics of tomato. Biocatalysis and Agricultural Biotechnology, 2016, 7, 127-133; DOI: 10.1016/j.bcab.2016.05.013

23. Cipollini, D. F. Consequences of the overproduction of methyl jasmonate on seed production, tolerance to defoliation and competitive effect and response of Arabidopsis thaliana. New Phytol. 2007, 173, 146-453. doi: 10.1111/j.1469-8137.2006.01882.x

24. Novoplansky, A. Picking battles wisely: plant behaviour under competition. Plant Cell Environ. 2009, 32, 726-741; DOI: 10.1111/j.1365-3040.2009.01979.x

25. Yamawo, A. Relatedness of neighboring plants alters the expression of indirect defense traits in a extrafloral nectary-bearing plant. Evol. Biol. 2015,42, 12-19; DOI: 10.1007/s11692-014-9295-2

26. Zhang, Qi, Zheng Xin-Yu., Lin Shun-Xian., Gu Cheng-Zhen., Li li., Li, Jia-Yu., Fang, Chang-Xun., He, Hai-Bin. Transcriptome analysis reveals that barnyard grass exudates increase the allelopathic potential of allelopathic and non-allelopathic rice (Oryza sativa) accessions. Rice 2019. 1939-8433; DOI: 10.1186/s12284-019-0290-1.10.1186/s12284-019-0290-1

27. Yang, C., Lee,. C., Chou, C. Effects of three allelopathic phenolics on chlorophyll accumulation of rice (Oryza sativa) seedlings: I. Inhibition of supply-orientation. Bot. Bull. Acad. Sin. 2002, 43, 299-304 